\title{
THE EFFECT OF BETA-BLOCKERS ON A COURSE OF CHRONIC HEART FAILURE IN PATIENTS WITH A LOW TRIIODOTHYRONINE SYNDROME
}

DOI: $10.36740 /$ WLek202007118

\author{
Sergiy M. Pyvovar, lurii S. Rudyk, Mykola P. Kopytsya, Tetiana V. Lozyk, Valentina Ir. Galchinskaya, \\ Tetiana 0. Chenchik \\ GOVERNMENT INSTITUTION “L.T.MALAYA THERAPY NATIONAL INSTITUTE OF THE NATIONAL ACADEMY OF MEDICAL SCIENCES OF UKRAINE”, \\ KHARKIV, UKRAINE
}

\begin{abstract}
The aim: The aim is to study the effect of $\beta-A B s$ in patients with $\mathrm{LT}_{3} \mathrm{~S}$ on the course of $\mathrm{HF}$.

Materials and methods: 354 patients with HF on a background of post-infarction cardiosclerosis were included in the 2-yeared follow-up study. LT S was diagnosed at 89 (25.1\%) patients. The levels of thyroid-stimulating hormone, free $\mathrm{T}_{3 \mathrm{f}}$ and $\mathrm{T}_{4 f^{\prime}}$ and reversible $\mathrm{T}_{3}$ were determined. The echocardioscopy was performed.

Results: Patients with HF in combination with $\mathrm{LT}_{3}$ S have a heavier functional class by NYHA, greater dilatation of the left heart cavities, less myocardial contractility, a higher frequency of atrial fibrillation and re-hospitalization. The use of $\beta$-ABs in patients with $\mathrm{HF}$ without $\mathrm{LT}_{3} \mathrm{~S}$ leads to a likely decrease in hospitalization frequency, while in patients with $\mathrm{LT}_{3} \mathrm{~S}$ it has an opposite effect. The frequency of rehospitalization increases with an excess of $\beta$-ABs dose $>5 \mathrm{mg}$ (equivalent to bisoprolol). At these patients a decrease in serum $\mathrm{T}_{3}$ level and negative dynamics of parameters of intracardiac hemodynamics are observed.

Conclusions: The use of $\beta$-ABs in patients with $\mathrm{LT}_{3}$ S leads to an increase in re-hospitalization at a dose over $5.0 \mathrm{mg}$ (equivalent to bisoprolol). In these patients there is a decrease in serum $\mathrm{T}_{3^{\prime}}$ an increase in $\mathrm{T}_{4}$ level; and the ejection fraction decrease; and heart cavities size increase.
\end{abstract}

KEY WORDS: low triiodothyronine syndrome, $\beta$-blockers, thyroid-stimulating hormone, ROC curve, risk, ventricular dilatation, reversible triiodothyronine, heart failure

Wiad Lek. 2020;73(7):1402-1409

\section{INTRODUCTION}

The progression of heart failure (HF) is a complex process affecting many organs and systems that leads to hormonal and immune alterations, including low triiodothyronine syndrome (low $\mathrm{T}_{3}$ syndrome, $\mathrm{LT}_{3} \mathrm{~S}$ ). The $\mathrm{LT}_{3} \mathrm{~S}$ is characterized by low levels of triiodothyronine $\left(\mathrm{T}_{3}\right)$, increased or normal reversible triiodothyronine $\left(\mathrm{T}_{3 \mathrm{r}}\right)$, normal or slightly altered levels of thyroid-stimulating hormone (TSH), and normal thyroxine $\left(\mathrm{T}_{4}\right)$ content, [1-3]. The occurrence of $\mathrm{LT}_{3} \mathrm{~S}$ in HF patients may reach $30 \%$ [3]. The $\mathrm{LT}_{3} \mathrm{~S}$ is associated with impaired peripheral conversion of inactive $\mathrm{T}_{4}$ to active $\mathrm{T}_{3}$ by deiodinases by increasing proinflammatory potential, hypoxia [4-8]. The $\mathrm{LT}_{3} \mathrm{~S}$ that accompanies HF can lead to a number of disorders, including the reduction of systolic heart function, the development of arrhythmias, increased vasoconstriction $[1,9-11]$. The $\beta$-blockers $(\beta-$ $\mathrm{AB}$ ) reduce mortality (up to $30 \%$ ) and morbidity in symptomatic patients with HF [12]. In addition, this group of medications did not show a significant effect on survival in decompensated patients. It is also known that $\beta$-ABs lead to blockade of deiodinases, which leads to a decrease in $\mathrm{T}_{3}$ to $\mathrm{T}_{4}$ conversion [13], thus they are prescribed to patients with hyperthyroidism. It may be supposed that the use of $\beta$-ABs in patients with $\mathrm{HF}$ in combination with $\mathrm{LT}_{3} \mathrm{~S}$ may increase its severity.

\section{THE AIM}

The aim is to study the effect of $\beta-\mathrm{ABs}$ in patients with $\mathrm{LT}_{3} \mathrm{~S}$ on the course of HF.

\section{MATERIALS AND METHODS}

The protocol of this prospective cohort study was approved by the local Ethics and Deontology Committee of Government Institution "L.T.Malaya Therapy National Institute" (Ukraine). All study procedures were performed in accordance with the ethical standards of the Declaration of Helsinki. From January 2015 to June 2019, we included patients in the study and conducted prospective follow-up (for 2 years). Patients were involved in the study on admission with the HF decompensation at the cardiology department. 354 patients with HF (110 women and 244 men) of the Caucasian race were included into the study. The inclusion criteria were: signed of the Patient Informed Consent, history of myocardial infarction (MI), verified diagnosis of HF II - IV functional classes (FC) by NYHA. The exclusion criteria: no informed consent, hemodynamically significant valvular heart defects, HF of other aetiology than cardiac infarction, hormone replacement therapy 
Table I. Characteristics of groups of patients with HF according to presence /absence of the I $\mathrm{LT}_{3} \mathrm{~S}\left(\mathrm{~T}_{3 \mathrm{f}}\right.$ criterion $\left.\leq 2.07 \mathrm{pmol} / \mathrm{I}\right)$

\begin{tabular}{|c|c|c|c|}
\hline \multirow{2}{*}{ Parameters } & \multicolumn{2}{|c|}{ Groups of patients with HF $(n=354)$} & \multirow{2}{*}{$\mathbf{P}$} \\
\hline & Without LT $S(n=265)$ & With $\mathrm{LT}_{3} \mathrm{~S}(\mathrm{n}=\mathbf{8 9})$ & \\
\hline 1 & 2 & 3 & 4 \\
\hline Age, years & $58,00[54,00-68,00]$ & $58,00[54,00-66,00]$ & 0,657 \\
\hline Male sex, n (\%) & $179(67,5)$ & $65(73)$ & $\begin{array}{l}X^{2}=0,936 \\
p=0,333\end{array}$ \\
\hline $\mathrm{IBM}, \mathrm{kg} / \mathrm{m}^{2}$ & $27,65[25,71-31,15]$ & $27,63[25,52-31,74]$ & 0,945 \\
\hline $\begin{array}{c}\text { NYHA FC, } \mathrm{n}(\%): \\
\text { II } \\
\text { III } \\
\text { IV } \\
\end{array}$ & $\begin{array}{c}124(46,8) \\
123(46,4) \\
18(6,8)\end{array}$ & $\begin{array}{l}18(20,2) \\
54(60,7) \\
17(19,1)\end{array}$ & $\begin{array}{l}x^{2}=24,642 \\
p=0,0001\end{array}$ \\
\hline Angina pectoris FC, $\mathrm{n}(\%)$ : & $\begin{array}{c}4(1,5) \\
29(10,9) \\
84(31,7)\end{array}$ & $\begin{array}{c}0 \\
10(11,2) \\
33(37,1)\end{array}$ & $\begin{array}{l}x^{2}=2,143 \\
p=0,543\end{array}$ \\
\hline Type 2 diabetes mellitus, $\mathrm{n}(\%)$ & $62(23,8)$ & $28(31,8)$ & $\begin{array}{l}X^{2}=2,236 \\
p=0,135\end{array}$ \\
\hline Coronary intervention, n (\%) & $19(7,2)$ & $9(10,1)$ & $\begin{array}{l}X^{2}=0,792 \\
p=0,374\end{array}$ \\
\hline Non-toxic goiter, n (\%) & $43(16,2)$ & $28(31,5)$ & $\begin{aligned} X^{2} & =9,644 \\
p & =0,002\end{aligned}$ \\
\hline Atrial fibrillation, n (\%) & $16(6,0)$ & $12(13,5)$ & $\begin{array}{l}X^{2}=5,070 \\
p=0,024\end{array}$ \\
\hline$\beta-A B, n(\%)$ & $208(78,8)$ & $74(86,0)$ & $\begin{array}{l}X^{2}=2,183 \\
p=0,140\end{array}$ \\
\hline - Carvedilol, n (\%) & $22(10,6)$ & $16(21,6)$ & $x^{2}=5,711$ \\
\hline - Bisoprolol, n (\%) & $186(89,4)$ & $58(78,4)$ & $\mathrm{p}=0,017$ \\
\hline ACEI, n (\%) & $225(84,9)$ & $81(91,0)$ & $\begin{array}{l}X^{2}=2,119 \\
p=0,146\end{array}$ \\
\hline ARB, n (\%) & $37(14,0)$ & $6(6,7)$ & $\begin{array}{l}X^{2}=3,255 \\
p=0,072\end{array}$ \\
\hline MRA, n (\%) & $125(47,2)$ & $40(44,9)$ & $\begin{array}{l}X^{2}=0,133 \\
p=0,716\end{array}$ \\
\hline Diuretics, n (\%) & $223(84,2)$ & $70(78,7)$ & $\begin{array}{l}X^{2}=1,413 \\
p=0,235\end{array}$ \\
\hline Ivabradine, n (\%) & $4(1,5)$ & $1(1,1)$ & $\begin{array}{l}X^{2}=0,071 \\
p=0,790\end{array}$ \\
\hline Digoxin, n (\%) & $60(22,6)$ & $19(21,3)$ & $\begin{array}{l}X^{2}=0,064 \\
p=0,800\end{array}$ \\
\hline $\mathrm{SBP}, \mathrm{mm} \mathrm{Hg}$ & $147,00[130,00-160,00]$ & $145,00[130,00-160,00]$ & 0,854 \\
\hline $\mathrm{DBP}, \mathrm{mm} \mathrm{Hg}$ & $90,00[80,00-100,00]$ & $90,00[80,00-100,00]$ & 0,944 \\
\hline $\mathrm{HR}, \mathrm{min}^{-1}$ & $74,00[66,50-82,00]$ & $75,00[66,00-84,00]$ & 0,613 \\
\hline $\mathrm{RBC}, 10^{12} / \mathrm{I}$ & $4,50[4,10-4,82]$ & $4,60[4,30-4,86]$ & 0,194 \\
\hline $\mathrm{Hb}, \mathrm{g} / \mathrm{l}$ & $140,00[128,00-150,00]$ & $141,00[134,00-150,00]$ & 0,194 \\
\hline WBC, $10^{9} / \mathrm{I}$ & $6,30[5,50-7,42]$ & $6,60[5,40-7,40]$ & 0,717 \\
\hline Granulocytes, $\%$ & $60,30[54,78-66,70]$ & $60,15[55,65-64,43]$ & 0,923 \\
\hline Lymphocytes, $\%$ & $30,00[24,60-36,70]$ & $31,40[26,55-35,05]$ & 0,367 \\
\hline Monocytes, $\%$ & $6,70[5,10-8,00]$ & $6,70[5,10-8,25]$ & 0,912 \\
\hline Platelets, $10^{9} / \mathrm{I}$ & $201,00[172,25-239,00]$ & $207,00[178,50-239,75]$ & 0,408 \\
\hline Creatinine, $\mu \mathrm{mol} / \mathrm{I}$ & $90,40[77,00-105,80]$ & $92,50[78,50-103,75]$ & 0,899 \\
\hline Glucose, $\mathrm{mmol} / \mathrm{I}$ & $5,47[4,80-6,51]$ & $5,72[4,93-6,73]$ & 0,377 \\
\hline Total cholesterol, mmol/ I & $4,71[3,77-5,70]$ & $54,88[3,77-5,91]$ & 0,753 \\
\hline $\mathrm{LDL}, \mathrm{mmol} / \mathrm{I}$ & $2,56[1,87-3,48]$ & $2,90[1,80-3,75]$ & 0,208 \\
\hline $\mathrm{HDL}, \mathrm{mmol} / \mathrm{I}$ & $1,10[0,95-1,37]$ & $1,00[0,88-1,25]$ & 0,030 \\
\hline $\mathrm{VLDL}, \mathrm{mmol} / \mathrm{l}$ & $0,69[0,46-1,07]$ & $0,77[0,52-1,06]$ & 0,326 \\
\hline $\mathrm{TG}, \mathrm{mmol} / \mathrm{I}$ & $1,49[1,03-2,26]$ & $1,63[1,08-2,21]$ & 0,635 \\
\hline $\mathrm{TSH}, \mathrm{mlU} / \mathrm{l}$ & $1,60[1,05-2,50]$ & $1,36[0,91-2,05]$ & 0,035 \\
\hline $\mathrm{T}_{3 f} \mathrm{pmol} / \mathrm{l}$ & $2,87[2,44-3,53]$ & $1,72[1,51-1,87]$ & 0,0001 \\
\hline $\mathrm{T}_{\Delta f} \mathrm{pmol} / \mathrm{l}$ & $14,24[11,11-16,52]$ & $14,89[12,46-16,32]$ & 0,308 \\
\hline $\mathrm{T}_{3, \mathrm{r}} \mathrm{pg} / \mathrm{ml}$ & $289,54[214,53-367,77]$ & $252,26[205,55-309,75]$ & 0,041 \\
\hline $\mathrm{T}_{3 f} / \mathrm{T}_{4 \mathrm{f}}$ ratio & $0,20[0,16-0,29]$ & $0,12[0,09-0,14]$ & 0,0001 \\
\hline LVEDD, $\mathrm{cm}$ & $5,40[5,00-5,80]$ & $5,60[5,20-6,00]$ & 0,020 \\
\hline LV EDV, $\mathrm{ml}$ & $143,15[119,86-168,62]$ & $155,61[131,23-182,17]$ & 0,059 \\
\hline LVESD, cm & $4,07[3,70-4,61]$ & $4,40[4,00-4,93]$ & 0,0001 \\
\hline LV ESV, ml & $74,09[59,10-99,23]$ & $89,00[71,11-115,743]$ & 0,0001 \\
\hline $\mathrm{IVS}, \mathrm{cm}$ & $1,20[1,10-1,22]$ & $1,20[1,10-1,21]$ & 0,792 \\
\hline LVPW, cm & $1,20[1,10-1,20]$ & $1,15[1,10-1,20]$ & 0,925 \\
\hline $\mathrm{LV} E F, \%$ & $45,97[37,22-55,17]$ & $38,19[32,18-48,05]$ & 0,0001 \\
\hline LV MM, g & $317,30[280,83-367,51]$ & $336,07[302,03-378,31]$ & 0,037 \\
\hline LV IMM, $\mathrm{g} / \mathrm{m}^{2}$ & $109,48[96,20-125,32]$ & $114,77[99,37-129,80]$ & 0,307 \\
\hline $\mathrm{LA}, \mathrm{cm}$ & $4,20[3,90-4,50]$ & $4,10[3,80-4,40]$ & 0,255 \\
\hline $\mathrm{ILA}, \mathrm{cm} / \mathrm{m}^{2}$ & $0,46[0,41-0,50]$ & $0,48[0,44-0,54]$ & 0,006 \\
\hline $\mathrm{RV}, \mathrm{cm}$ & $2,70[2,58-3,00]$ & $2,80[2,60-3,00]$ & 0,302 \\
\hline $\mathrm{RA}, \mathrm{cm}$ & $3,70[3,50-4,00]$ & $3,60[3,50-3,98]$ & 0,523 \\
\hline
\end{tabular}

Notes: SBP - Systolic blood pressure; DBP - diastolic blood pressure, HR - heart rate, TG - triacylglycerides, ACEI - angiotensin-

converting-enzyme inhibitors, ARB - angiotensin II receptor blockers, MRA - Mineralocorticoid receptor antagonists. 
with L-thyroxine, thyro-suppressive treatment, clinical or subclinical hypothyroidism, pathothyroidism, inflammatory diseases, other serious pathologies (neoplasm, tuberculosis), which could complicate treatment or reduce life expectancy. Diagnosis of HF and treatment of patients were performed according to the recommendations of the European Society of Cardiologists [14].

For pateintes doppler echocardioscopy was performed using the VIVID-3 ultrasonic diagnostic system (General Electric, USA). End-diastolic and end-systolic dimensions (EDD and ESD respectively) of the left ventricle (LV), the thickness of the interventricular septum (IVS), the LV posterior wall (LVPW), the diameter of the left atrium (LA), right ventricle (RV), other options were determined. The left ventricle end-diastolic volume (LV EDV) and the end-systolic volume (LV ESV), the ejection fraction (LVEF) of the left ventricle, the left atrium index (ILA), the mass of the LV myocardium (MM LV) and its index (IMM LV) were calculated.

To determine blood serum levels of thyroid-stimulating hormone (TSH) (normal range 0.3-4.0 mIU / 1), free $\mathrm{T}_{3}$ $\left(\mathrm{T}_{3 \mathrm{f}}\right)$ (normal range 2.5-5.8 pmol / $\mathrm{l}$ ) and free $\mathrm{T}_{4}\left(\mathrm{~T}_{4 \mathrm{f}}\right)$ ) (normal range - 10-25 pmol/ l) reagent kits (ELISA "TSH", " $\mathrm{T}_{4 \mathrm{f}}$ " and " $\mathrm{T}_{3 \mathrm{f}}$ " by Hema, Ukraine) were used. The level of reversible triiodothyronine $\left(\mathrm{T}_{3 \mathrm{r}}\right)$ (normal range - 90-350 $\mathrm{pg} / \mathrm{ml}$ ) was determined using an ELISA kit reagent (Elabscience ${ }^{\oplus}$, China). Immunoferment studies were performed on a semi-automatic enzyme-linked immunosorbent analyser "Immunochem-2100" (High technology, USA). Durin the biennial follow-up period the course of HF was evaluated, the frequency of repeated hospitalizations for decompensation of the disease, mortality, the dynamics of thyroid hormones levels and parameters of intracardiac hemodynamics were studied.

The analysis of the normality of the distribution of indicators was performed using the Shapiro - Wilk test. Continuous variables are given as the median $(\mathrm{Me})$ and the interquantile range (for non-normally distributed variables) or as the mean $(\mathrm{M})$ and the standard deviation $( \pm \mathrm{SD})$ (in the case of the normal distribution). The quantitative indicators were compared using a non-parametric criterion - Mann - Whitney and a paired T-test (in the study of parameter dynamics). The categorical variables were compared using the Pearson's chi-squared test $\left(\chi^{2}\right)$ (Yates correction for traits less than 10). The receiver operating characteristic (ROC) curves were analysed to determine the prognostic level of $\mathrm{T}_{3 \mathrm{f}}$ The relative risk (RR) of re-hospitalization and mortality was calculated with a $95 \%$ confidence interval (CI). P-value less than 0.05 was considered as statistically significant. Statistical processing was performed using IBM $^{\circledast}$ SPSS $^{\circledast}$ Statistics, 20.0 (free-download full Version) and MedCalc, 18.9.1 (free version) software packages.

\section{RESULTS}

Previously we reported that the threshold level of $\mathrm{T}_{3 \mathrm{f}}$ for the low T3 syndrome below the lower threshold of its normal range (2.5 pmol / l) did not demonstrate a relationship of this state with peculiarities of the HF course. The threshold value was reduced to $\leq 2.07 \mathrm{pmol} / \mathrm{l}$ and the effect of $\mathrm{LT}_{3} \mathrm{~S}$ on HF course was studied [15].

At the initial stage of the statistical analysis, all patients with HF were divided into 2 groups: the first group included 265 (74.9\%) patients who had normal levels of $\mathrm{T}_{3 \mathrm{p}}$ $\mathrm{T}_{4 \mathrm{P}}$ and TSH (Table I); in the second - $89(25.1 \%)$ patients with $\mathrm{T}_{3 \mathrm{f}}$ level $\leq 2.07 \mathrm{pmol} / \mathrm{l}$ at normal $\mathrm{T}_{4 \mathrm{f}}$ and TSH levels. These patients were diagnosed with $\mathrm{LT}_{3} \mathrm{~S}$.

In the group of patients with HF in combination with $\mathrm{LT}_{3} \mathrm{~S}$ II FC by NYHA was in $20.2 \%$ of patients, compared to $46.8 \%$ in the group without this syndrome, III FC by NYHA was in $60.7 \%$ of patients, versus $46.4 \%$ in another group and IV FC was in $19.1 \%$ of patients, versus $6.8 \%$ in the group without this syndrome $\left(\chi^{2}=24.642 ; \mathrm{p}=0.0001\right)$; these patients more often had non-toxic goiter $(31.5 \%$ versus $16.2 \%,\left(\chi^{2}=9.644 ; \mathrm{p}<0.002\right)$ and atrial fibrillation $\left(13.5 \%\right.$ vs. $6.0 \%,\left(\chi^{2}=5.070 ; \mathrm{p}<0.024\right)$ (Table I).

The patients with $\mathrm{LT}_{3} \mathrm{~S}$ compared with patients without it, had lower HDL (by 9.1\%, p = 0.030); TSH (by 15.0\%, p = 0.035 ), $\mathrm{T}_{3 \mathrm{f}}$ (by $36.6 \%, \mathrm{p}=0.0001$ ), $\mathrm{T}_{3 \mathrm{r}}$ (by $12.9 \%, \mathrm{p}=0.041$ ) levels, and $\mathrm{T}_{3 \mathrm{f}} / \mathrm{T}_{4 \mathrm{f}}$ ratio ( by 40.0\%, $\mathrm{p}=0.0001$ ); higher $\mathrm{LV}$ EDD (by 3.7\%, p = 0.020), LV ESD (by 7.2\%, p = 0.0001), LV ESV (by 20.1\%, p = 0.0001), MM (by 5.9\%, p = 0.037) and ILA (by $4.3 \%, \mathrm{p}=0.006$ ); lower LV EF value (by $7.9 \%$, $\mathrm{p}=0.0001$ ) (see Table I).

The patients in both groups did not differ in HF therapy. However, patients with $\mathrm{LT}_{3} \mathrm{~S}$ were more likely to take carvedilol $(21.6 \%$ vs. $10.6 \%, p=0.017)$, comparing to patients of another group.

The hospitalization frequency due to HF decompensation within 2 years, among patients with $\mathrm{LT}_{3} \mathrm{~S}$, was higher (55.1\%, vs. $20.4 \%, \mathrm{p}=0.0001)$.

The relative risk of re-hospitalization of HF patients with $\mathrm{LT}_{3} \mathrm{~S}$ within 2 years was 2.098 [1.506 - 2.921] $(\mathrm{p}=$ $0.0001)$. The relative risk of death of these patients during the specified period, was $1.642[0.711-3.797](p=0.245)$. Thus, the presence of $\mathrm{LT}_{3} \mathrm{~S}$ significantly increased the relative risk of re-hospitalization within 2 years from 20,4 to $55,1 \%$ (see Table II).

The effect of the $\beta$-ABs use on the frequency of rehospitalization due to HF decompensation was analyzed (Table III).

In the group of patients with $\mathrm{HF}$ without $\mathrm{LT}_{3} \mathrm{~S}$, the frequency of re-hospitalization was lower when using beta-blockers, compared to that in patients who could not take this group of medication due to side effects $(16.3 \%$ vs. $35.1 \%$, respectively, $\mathrm{p}=0.002$ ). The relative risk of re-hospitalization in this group when using $\beta$-blockers is 0.466 $[0.291-0.744](p=0.0014)$. Thus, the use of $\beta$-blockers in the group of patients with $\mathrm{HF}$ without $\mathrm{LT}_{3} \mathrm{~S}$ leads to a $53.6 \%$ reduction in the relative risk of re-hospitalization within 2 years.

In the group of patients with HF, flowing on the background of $\mathrm{LT}_{3} \mathrm{~S}$, taking $\beta-\mathrm{AB}$, there is a tendency to increase the frequency of re-hospitalization, compared with that in patients who were unable to take this group 
Table II. The Biennial rehospitalisation and mortality.

\begin{tabular}{|c|c|c|c|}
\hline \multirow{2}{*}{ Parameters } & \multicolumn{2}{|c|}{ Groups of patients with HF $(n=354)$} & \multirow{2}{*}{$X^{2}(p)$} \\
\hline & Without LT 3 S $(n=265)$ & With $\mathrm{LT}_{3} \mathrm{~S}(\mathrm{n}=89)$ & \\
\hline Rehospitalisation, $\mathrm{n}(\%)$ & $54(20,4)$ & $49(55,1)$ & $38,838(0,0001)$ \\
\hline Mortality, n (\%) & $14(5,3)$ & $8(9,0)$ & $1,570(0,210)$ \\
\hline
\end{tabular}

Table III. $\beta$-Abs effect on biennial rehospitalization and mortality

\begin{tabular}{|c|c|c|c|}
\hline \multirow{2}{*}{ Parameters } & \multicolumn{2}{|c|}{ All patients with HF $(n=354)$} & \multirow{2}{*}{$X^{2}(p)$} \\
\hline & Without $\beta$-ABs $(n=72)$ & With $\beta$-ABs $(n=282)$ & \\
\hline Rehospitalization, n (\%) & $25(34,7)$ & $78(27,7)$ & $1,387(0,239)$ \\
\hline \multirow[t]{3}{*}{ Mortality, n (\%) } & $6(8,3)$ & $16(5,7)$ & $0,694(0,405)$ \\
\hline & \multicolumn{2}{|c|}{ Patientes with HF without $\mathrm{LT}_{3} \mathrm{~S}(\mathrm{n}=265)$} & \\
\hline & Without $\beta$-ABs $(n=57)$ & With $\beta$-ABs $(n=208)$ & \\
\hline Rehospitalization, n (\%) & $20(35,1)$ & $34(16,3)$ & $9,685(0,002)$ \\
\hline \multirow[t]{3}{*}{ Mortality, n (\%) } & $3(5,3)$ & $11(5,3)^{\prime}$ & $0,107^{*}(0,744)$ \\
\hline & \multicolumn{2}{|c|}{ Patientes with HF with $\mathrm{LT}_{3} \mathrm{~S}(\mathrm{n}=89)$} & \\
\hline & Without $\beta$-ABs $(n=15)$ & With $\beta$-ABs $(n=74)$ & \\
\hline Rehospitalization, n (\%) & $5(33,3)$ & $44(59,5)$ & $3,440(0,064)$ \\
\hline Mortality, n (\%) & $3(20,0)$ & $5(6,8)$ & $1,300 *(0,255)$ \\
\hline
\end{tabular}

Note * ${ }^{*}$ Yates

Table IV. Dependence of frequency of hospitalization and mortality on type of $\beta-A B$

\begin{tabular}{|c|c|c|c|}
\hline \multirow{2}{*}{ Parameters } & \multicolumn{2}{|c|}{ Patients with HF without $\mathrm{LT}_{3} \mathrm{~S}(\mathrm{n}=\mathbf{2 6 5})$} & \multirow{2}{*}{$x^{2}(p)$} \\
\hline & Carvedilol $(n=22)$ & Bisoprolol $(n=186)$ & \\
\hline Rehospitalization, n (\%) & $8(36,4)$ & $26(14,0)$ & $7,201(0,007)$ \\
\hline \multirow[t]{3}{*}{ Mortality, n (\%) } & 0 & $11(5,9)$ & $1,374(0,241)$ \\
\hline & \multicolumn{2}{|c|}{ Patients with $\mathrm{HF}$ and $\mathrm{LT}_{3} \mathrm{~S}(\mathrm{n}=89)$} & \\
\hline & Carvedilol $(n=16)$ & Bisoprolol $(n=58)$ & \\
\hline Rehospitalization, n (\%) & $11(68,8)$ & $33(56,9)$ & $0,731(0,393)$ \\
\hline Mortality, n (\%) & $2(12,5)$ & $3(5,2)$ & $1,069(0,301)$ \\
\hline
\end{tabular}

of drugs (59.5\%, vs. $33.3 \%$, respectively, p = 0,064) (see Table. 3). The relative risk of re-hospitalization in the LT $S$ group when using $\beta$-ABs was $2.378[1,088-5,199]$ ( $\mathrm{p}=$ 0.029 ). Thus, the use of $\beta$-blockers in patients with HF in combination with $\mathrm{LT}_{3} \mathrm{~S}$ significantly increases the risk of re-hospitalization from $33.3 \%$ to $59.5 \%$.

In the group of patients with $\mathrm{HF}$ without $\mathrm{LT}_{3} \mathrm{~S}, 22$ patients received carvedilol and 186 - bisoprolol. The incidence of re-hospitalization in the bisoprolol subgroup (14.0\%) was significantly lower, compared to that with carvedilol (36.4) $(\mathrm{p}=0.007)$. No significant difference in mortality was found.

In the $\mathrm{LT}_{3} \mathrm{~S}$ group, 16 patients were treated with carvedilol and 58 with bisoprolol. No significant difference was found in the effect of carvedilol, compared with bisoprolol, on the frequency of hospitalization and mortality in patients with $\mathrm{LT}_{3} \mathrm{~S}$ (see Table IV).

Taking into account small subgroups of patients with $\mathrm{LT}_{3} \mathrm{~S}$ taking bisoprolol or carvedilol, for further analysis a unifying dose of these drugs was performed according to the scheme presented in [16].

A ROC analysis was performed to stratify the dose of $\beta$-ABs affecting the risk of re-hospitalization in patients with HF. The incidence of hospitalization in the group of patients with $\mathrm{HF}$ without $\mathrm{LT}_{3} \mathrm{~S}$ was found to be higher at a dose of $\leq 5.0 \mathrm{mg}$ (equivalent to bisoprolol), comparing to a higher dose (sensitivity $-85.00 \%$ and specificity $-47.41 \%$, $\mathrm{p}=0,0001)$.

At the same time, ROC analysis showed the opposite effect of $\beta$-ABs in the group of patients with $\mathrm{LT}_{3} \mathrm{~S}$. The re-hospitalization incidence of patients with HF in combination with $\mathrm{LT}_{3} \mathrm{~S}$ increases when the optimal cut-off value for the $\beta$-ABs dose exceeds $5 \mathrm{mg}$ (equivalent to bisoprolol) (sensitivity $-67.35 \%$ and specificity $-57.50 \%, \mathrm{p}=0.025$ ) (see Table V).

Among all patients, the biennial hospitalization frequency when using $\beta$-ABs at a dose less or equal to $5 \mathrm{mg}$ was $33.5 \%$, compared with $23.7 \%$ when receiving over $5 \mathrm{mg}$ 
Table V. Relationship of $\beta$-ABs dose (equivalent to bisoprolol) with rehospitalization (ROC analysis)

\begin{tabular}{|c|c|c|c|c|c|c|}
\hline Group & Cut-off value & $\begin{array}{l}\text { Area under the } \\
\text { curve (AUC) }\end{array}$ & $95 \% \mathrm{Cl}$ & $\begin{array}{c}\text { Sensitivity, } \\
\%\end{array}$ & Specificity, \% & $\mathbf{p}$ \\
\hline $\begin{array}{l}\text { All patients with HF ( } \mathrm{n} \\
\qquad=354)\end{array}$ & $\leq 2,5 \mathrm{mg}$ & 0,549 & $0,498-0,600$ & 35,78 & 73,90 & 0,131 \\
\hline $\begin{array}{l}\text { HF without } \mathrm{LT}_{3} \mathrm{~S} \\
(\mathrm{n}=265)\end{array}$ & $\leq 5,0 \mathrm{mg}$ & 0,686 & $0,630-0,739$ & 85,00 & 47,41 & 0,0001 \\
\hline $\begin{array}{l}\mathrm{HF} \text { with } \mathrm{LT}_{3} \mathrm{~S} \\
(\mathrm{n}=89)\end{array}$ & $>5,0 \mathrm{mg}$ & 0,634 & $0,525-0,733$ & 67,35 & 57,50 & 0,025 \\
\hline
\end{tabular}

Table VI. Dependence of re-hospitalization incidence on dose of $\beta$-ABs ( $n(\%)$ )

\begin{tabular}{|c|c|c|}
\hline \multicolumn{2}{|c|}{ All patients with HF $(n=354)$} & \multirow[t]{2}{*}{$X^{2}(p)$} \\
\hline$\leq 5 \mathrm{mg}(\mathrm{n}=194)$ & $>5 \mathrm{mg}(\mathrm{n}=160)$ & \\
\hline $65(33,5)$ & $38(23,7)$ & $4,033(0,045)$ \\
\hline \multicolumn{2}{|c|}{ Patients with HF without $\mathrm{LT}_{3} \mathrm{~S}(\mathrm{n}=265)$} & \\
\hline$\leq 5 \mathrm{mg}(\mathrm{n}=155)$ & $>5 \mathrm{mg}(\mathrm{n}=110)$ & \\
\hline $49(31,6)$ & $5(4,5)$ & $29,053(0,0001)$ \\
\hline \multicolumn{2}{|c|}{ Patients with HF and $\mathrm{LT}_{3} \mathrm{~S}(\mathrm{n}=89)$} & \\
\hline$\leq 5 \mathrm{mg}(\mathrm{n}=39)$ & $>5 \mathrm{mg}(\mathrm{n}=50)$ & \\
\hline $16(41,0)$ & $33(60,0)$ & $5,523(0,019)$ \\
\hline
\end{tabular}

$(\mathrm{p}=0.045)($ Table IV). The relative risk of re-hospitalization with $\beta$-ABs dose exceeding $5 \mathrm{mg}$ was 0.709 [0.504 - 0.977] $(p=0.048)$. It can be concluded that the use of $\beta-A B s$ in such dose at $\mathrm{HF}$ (without $\mathrm{LT}_{3} \mathrm{~S}$ ) reduces the relative risk of re-hospitalization by $29.3 \%$.

Among patients with $\mathrm{HF}$ without $\mathrm{LT}_{3} \mathrm{~S}$, the biennial re-hospitalization incidence when using $\beta$-ABs at a dose less or equal to $5 \mathrm{mg}$ was $31.6 \%$, compared with $4.5 \%$ when receiving over $5 \mathrm{mg}(\mathrm{p}=0.0001)$.

The relative risk of re-hospitalization of these patients using dose of $\beta$-blockers over $5 \mathrm{mg}$ was 0.144 [0.059 - 0.349] $(\mathrm{p}=0.0001)$. Thus, the use of $\beta-\mathrm{ABs}>5 \mathrm{mg}$ in the group of patients with $\mathrm{HF}$ without $\mathrm{LT}_{3} \mathrm{~S}$ reduces the relative risk of re-hospitalization.

In the group of patients with HF in combination with $\mathrm{LT}_{3} \mathrm{~S}$, the biennal re-hospitalization incidence when using $\beta$-Ảs at a dose of less or equal to $5 \mathrm{mg}$ was $41.0 \%$, compared to $60.0 \%$ when receiving over $5 \mathrm{mg}(\mathrm{p}=0.019)$ (see Table VI). The relative risk of re-hospitalization in patients with $\mathrm{LT}_{3} \mathrm{~S}$ taken $\beta$-ABs $>5 \mathrm{mg}$ was 1.609 [1,051 - 2,462] $(p=0.029)$. Thus, the use of $\beta-A B s>5 \mathrm{mg}$ in the group of patients with HF in combination with $\mathrm{LT}_{3} \mathrm{~S}$ increases the relative risk of re-hospitalization by $46.3 \%$.

In order to study the effect of different doses of $\beta$-ABs on the dynamics of parameters of intra-cardiac hemodynamics and thyroid hormones levels for 2 years, patients with $\mathrm{HF}$ and $\mathrm{LT}_{3} \mathrm{~S}$ were divided into 2 groups. The first group included 39 (43.8\%) patients who failed to increase the dose of $\beta$-ABs over $5 \mathrm{mg}$ due to side effect. The second group included $50(56.2 \%)$ patients taking $\beta$-blockers at a dose over $5 \mathrm{mg}$. In the group of patients with $\mathrm{LT}_{3} \mathrm{~S}$ with a dose of $\beta$-ABs below and equal to $5 \mathrm{mg}$ for 2 years, there was an increase in $\mathrm{T}_{3 \mathrm{f}}$ level (by $0.185 \pm 0.413 \mathrm{pmol} / \mathrm{l}, \mathrm{p}=$
0.011 ), a decrease in ESD (by $0.480 \pm 1.079 \mathrm{~cm}, \mathrm{p}=0.008$ ) and ESV (20.734 $\pm 6.984 \mathrm{ml}, \mathrm{p}=0.029)$, an increase in LV EF value (by $10.053 \pm 13.370 \%, p=0.0001$ ); decrease in LA $(0.262 \pm 0.719 \mathrm{~cm}, \mathrm{p}=0.035)$ and $\mathrm{RV}$ size $(0.208 \pm$ $0.372 \mathrm{~cm}, \mathrm{p}=0.010)$.

In addition, in the subgroup of patients with $\mathrm{LT}_{3} \mathrm{~S}$ receiving $\beta$-ABs at a dose exceeding $5 \mathrm{mg} /$ day during 2 years a decrease in serum $\mathrm{T}_{3 \mathrm{f}}$ level (by $0.107 \pm 0.275 \mathrm{pmol} / \mathrm{l}$, $\mathrm{p}=0.014$ ), an increase of the $\mathrm{T}_{4 \mathrm{f}}$ level (by 1,148 $\pm 2,245$ $\mathrm{pmol} / \mathrm{l}, \mathrm{p}=0.002)$, the decrease in the value of the $\mathrm{T}_{3 \mathrm{f}} / \mathrm{T}_{4 \mathrm{f}}$ ratio (by $0.018 \pm 0.035, \mathrm{p}=0.002$ ); increase in LV EDD (by $0.350 \pm 0.813 \mathrm{~cm}, \mathrm{p}=0.004$ ), LV EDV (by $24.800 \pm 5.14 \mathrm{ml}, \mathrm{p}=0.003$ ), LV ESD (by $0.342 \pm 1.045 \mathrm{~cm}$, $\mathrm{p}=0.003$ ), LV ESV (by $21.325 \pm 48.750 \mathrm{ml}, \mathrm{p}=0.004$ ), ILA $(0.947 \pm 0.221 \mathrm{~cm}, \mathrm{p}=0.0001)$, and $\mathrm{RV}(0.419 \pm 0.586 \mathrm{~cm}$, $\mathrm{p}=0.0001)$ were observed.

\section{DISCUSSION}

The thyroid secretes several hormones, including $\mathrm{T}_{4}, \mathrm{~T}_{3}$, and $\mathrm{T}_{3 \mathrm{r}}$ and it is the sole source of $\mathrm{T}_{4}$. Unlike the latter, $\mathrm{T}_{3}$ (biologically more active hormone) is secreted by the thyroid gland not more than $20 \%$ of the total level. The remaining $\mathrm{T}_{3}$ is synthesized by other tissues (outside the thyroid gland) by enzymaticly removing the iodine atom from the $\mathrm{T}_{4}$ molecule by deiodinases, which exist in several forms. Type I deiodinase $\left(D_{1}\right)$ is primarily found in the liver and kidneys and is responsible for the synthesis of $80 \%$ of $\mathrm{T}_{3}$. Type II deiodinase $\left(\mathrm{D}_{2}\right)$ is mostly located in the brain and muscles, including the human heart, and regulates $\mathrm{T}_{3}$ tissue concentration. Type III $\left(\mathrm{D}_{3}\right)$ deiodinase, converting $\mathrm{T}_{4}$ to reversible $\mathrm{T}_{3}$ (inactive), decreases serum $\mathrm{T}_{3 \mathrm{f}}$ level [17]. $\mathrm{T}_{3 \mathrm{f}}$ penetrates the membrane into the cell and is responsible 
Table VII. Dependence of thyroid hormone dynamics and intracardiac haemodynamic parameters on dose of $\beta$-ABs in patients with HF in combination with LT $S(n=89)$.

\begin{tabular}{|c|c|c|}
\hline \multirow{2}{*}{ Parameters } & \multicolumn{2}{|c|}{ Dose of $\beta$-ABs } \\
\hline & $\leq 5 \mathrm{mg}(\mathrm{n}=39)$ & $>5 \mathrm{mg}(\mathrm{n}=50)$ \\
\hline 1 & 2 & 3 \\
\hline TSH, mIU/l & $+0,027 \pm 0,809(p=0,833)$ & $+0,155 \pm 0,895(p=0,259)$ \\
\hline $\mathrm{T}_{3 \mathrm{f}^{\prime}} \mathrm{pmol} / \mathrm{l}$ & $+0,185 \pm 0,413(p=0,011)$ & $-0,107 \pm 0,275(p=0,014)$ \\
\hline $\mathrm{T}_{4 \mathrm{f}^{\prime}} \mathrm{pmol} / \mathrm{l}$ & $+0,539 \pm 2,926(p=0,276)$ & $+1,148 \pm 2,245(p=0,002)$ \\
\hline $\mathrm{T}_{3 \mathrm{f}} / \mathrm{T}_{4 \mathrm{f}}$ ratio & $-0,0002 \pm 0,0607(p=0,980)$ & $-0,018 \pm 0,035(p=0,002)$ \\
\hline LV EDD, cm & $-0,221 \pm 1,045(p=0,194)$ & $+0,350 \pm 0,813(p=0,004)$ \\
\hline LV EDV, ml & $-13,249 \pm 73,454(p=0,267)$ & $+24,800 \pm 5,140(p=0,003)$ \\
\hline LV ESD, cm & $-0,480 \pm 1,079(p=0,008)$ & $+0,342 \pm 1,045(p=0,026)$ \\
\hline LV ESV, ml & $-20,734 \pm 6,984(p=0,029)$ & $+21,325 \pm 48,750(p=0,004)$ \\
\hline LV EF, \% & $+10,053 \pm 13,370(p=0,0001)$ & $-3,245 \pm 17,367(p=0,197)$ \\
\hline $\mathrm{LA}, \mathrm{cm}$ & $-0,262 \pm 0,719(p=0,035)$ & $+0,060 \pm 0,657(p=0,526)$ \\
\hline $\mathrm{ILA}, \mathrm{cm} / \mathrm{m}^{2}$ & $+0,911 \pm 0,183(p=0,0001)$ & $+0,947 \pm 0,221(p=0,0001)$ \\
\hline $\mathrm{RV}, \mathrm{cm}$ & $-0,208 \pm 0,372(p=0,010)$ & $+0,419 \pm 0,586(p=0,0001)$ \\
\hline $\mathrm{RA}, \mathrm{cm}$ & $-0,165 \pm 0,619(p=0,214)$ & $+0,067 \pm 0,649(p=0,515)$ \\
\hline
\end{tabular}

for genomic and non-genomic effects. $\mathrm{T}_{3}$ has a positive inotropic and chronotropic effect on the myocardium, regulating the transcription of myocyte-specific genes [17]. $\mathrm{T}_{3}$ directly affects vascular unstriated muscles, contributing to dilatation of arterioles and reduced peripheral vascular resistance. For normal functioning of the cardiovascular system, optimal concentrations of thyroid hormones are necessary; their excess or deficiency have a disintegrating effect. A decrease in serum $\mathrm{T}_{3}$ concentration and a parallel increase in $\mathrm{T}_{3 \mathrm{r}}$ are a common result of many diseases, such as injuries, starvation and post-surgery conditions. [18] Such changes in function of "Hypothalamic-pituitary-thyroid " axis, are generally called as $\mathrm{LT}_{3} \mathrm{~S}$. In the fasting state, this transition from the production of the metabolically potent hormone $\mathrm{T}_{3}$ to the synthesis of the metabolic-inactive inverse (reversible) $\mathrm{T}_{3 \mathrm{r}}$ plays a compensatory role. However, in chronic conditions, such as HF and depression, low $\mathrm{T}_{3}$ concentration can cause adverse effects [18]. The main mechanism of low serum $\mathrm{T}_{3}$ concentration in patients with nontyroid disease is reduced $\mathrm{D}_{1}$ activity in the liver. Increased concentrations of cytokines, such as interleukin- 6 and tumor necrosis factor $\alpha$, cause violation of hepatic $\mathrm{D}_{1}$ expression. Other mechanisms involved in the pathogenesis of low $\mathrm{T}_{3}$ syndrome include a decrease in the concentration of thyroid hormone binding proteins and a decrease in the secretion of thyroid hormone and TSH. Dopamine secretion and prolonged hypercortisolemia may play a role in this process [18]. There is no consensus in the literature regarding the criteria for defining low $\mathrm{T}_{3}$ syndrome. So in $[19,20]$ a lower value of the range of the norm $\mathrm{T}_{3 \mathrm{p}}$ which ranged from 4.0 to $2.5 \mathrm{pmol} / \mathrm{l}$, at normal levels of $\mathrm{T}_{4 \mathrm{f}}$ and TSH are used. In the Articles of the Italian researchers $[21,22]$ new ones in addition to the above mentioned parameters, an additional criterion - an increased $\mathrm{T}_{3 \mathrm{r}}$ level is introduced. In the previous work, we were unable to form a representative group of patients with HF with decreased $\mathrm{T}_{3 \mathrm{f}}$ levels, normal TSH and $\mathrm{T}_{4 \mathrm{f}}$ concentrations, and increased $\mathrm{T}_{3 \mathrm{r}}$ levels [15]. It has also been demonstrated that the risk of re-hospitalization of patients with HF with regard to decompensation of the disease increases when reaching the cut-off value for serum $\mathrm{T}_{3 \mathrm{f}}$ concentration below or equal to $2.07 \mathrm{pmol} / \mathrm{l}$ [15]. In our study, the incidence of $\mathrm{LT}_{3} \mathrm{~S}\left(\mathrm{~T}_{3 \mathrm{f}} \leq 2.07 \mathrm{pmol} / \mathrm{l}\right)$ in patients with $\mathrm{HF}$ is $25.1 \%$.

According to Japanese researchers, even patients with HF of I FC by NYHA and in the stage of compensation have some early manifestations of $\mathrm{LT}_{3} \mathrm{~S}$ [19]. In patients with $\mathrm{HF}$, this syndrome is associated with poor LV function, tachyarrhythmia and increased mortality [23]. A low $\mathrm{T}_{3}$ concentration in $\mathrm{HF}$ is a stronger prognostic predictor than dyslipidemia, age, or LV EF [23]. We revealed that in the group $\mathrm{HF}$ in combination with the $\mathrm{LT}_{3} \mathrm{~S}$ patients have a more severe NYHA functional class, they have more often atrial fibrillation, more severe dilatation of cavities of the left parts of the heart and less contractile capacity of myocardium, higher incidence of rehospitalization due to HF decompensation during two years.

Clinical trial results showed that $\beta$-ABs has a positive effect on the clinical course of $\mathrm{HF}$ and reduces the risk of five-year mortality by $30 \%$ [12, 24, 25]. In Recommendations of the European Society of Cardiologists (ESC) [14] and the American College of Cardiologists and the American Association of Cardiologists (ACC / ANA) [26] it is emphasized that $\beta$-ABs are a first-line drug for the treatment of patients with HF. In addition, $\beta$-ABs has also long been used in the treatment of symptomatic patients with thyrotoxicosis. This drugs block metabolism of thyroid hormones by inhibiting $\mathrm{D}_{1}$ outside the glandula [13]. This effect is inherent in the 
non-selective $\beta$-ABs [27], but it is also characteristic of selective medication $[28,29]$. In patients a decrease in serum $\mathrm{T}_{3}$ concentration $[30,31]$ and an increase in $\mathrm{T}_{3 \mathrm{r}}$ levels by inhibiting its breakdown are observed. Usually, patients remain euthyroid and have stable serum TSH values [29]. But in patients with low thyroid hormones levels (including $\mathrm{LT}_{3} \mathrm{~S}$ ) at the start of $\beta$-ABs treatment, this phenomenon may have clinical implications in the long term [32]. Clinical manifestations of $\beta$-ABs withdrawal are also associated with sharp fluctuations in thyroid levels [33, 34].

During the statistical analysis, we revealed that the use of $\beta$-ABs in patients with HF without $\mathrm{LT}_{3} \mathrm{~S}$ leads to a likely reduction in re-hospitalization within 2 years. At the same time, in the presence of LT $S \beta$-blockers led to an increase in the frequency of re-hospitalization of patients due to HF decompensation. Using ROC analysis, it was found out that the incidence of re-hospitalization in the group of patients with $\mathrm{HF}$ without $\mathrm{LT}_{3} \mathrm{~S}$ was higher at a dose of $\beta$-ABs below and equal to $5.0 \mathrm{mg}$ (equivalent to bisoprolol), compared to a higher dose. The reverse effect of $\beta$-ABs was detected in the group of patients with $\mathrm{LT}_{3} \mathrm{~S}$. The risk of re-hospitalization of patients with HF in combination with low $\mathrm{T}_{3}$ syndrome increases with an excess of $\beta$-blockers dose over $5 \mathrm{mg}$. In the subgroup of patients receiving $\beta$-ABs at a dose over $5 \mathrm{mg} /$ day, within 2 years a decrease in serum $T_{3 f}$ level and the $\mathrm{T}_{3 \mathrm{f}} / \mathrm{T}_{4 \mathrm{f}}$ ratio, an increase in $\mathrm{T}_{4 \mathrm{f}}$ level,; further enlargement of the heart cavities and reduction of LV EF were observed. This may indicate further growth affect of low triiodothyronine syndrome.

Thus, it is likely that at the beginning of the treatment by $\beta$-ABs in patients with HF it is necessary to exclude the presence of $\mathrm{LT}_{3} \mathrm{~S}$. It is not advisable to titrate a dose of $\beta$-ABs higher than $5 \mathrm{mg}$ (equivalent to bisoprolol) in patients with $\mathrm{HF}$ in combination with $\mathrm{LT}_{3} \mathrm{~S}$.

Our research has strengths and weaknesses. The advantage is the study protocol and very strict inclusion criteria. Unlike other studies, this approach has allowed the creation of a very homogeneous group with the exclusion of patients with sub- and clinical thyroid dysfunction, with concomitant pathology that may affect hormone levels. On the other hand, such criteria did not allow the formation of a large group of patients with $\mathrm{LT}_{3} \mathrm{~S}$ who received $\beta$-ABs with different selectivity to receptors. Also, our study is limited to 2 years of follow-up period.

\section{CONCLUSIONS}

The incidence of low triiodothyronine syndrome in patients with heart failure is $25.1 \%$. Patients in this category have more severe NYHA functional class, more frequent atrial fibrillation, greater dilatation of the left heart cavities and less myocardial contractility, a higher frequency of re-hospitalization for HF decompensation over two years. The use of $\beta$-blockers in patients with heart failure without low triiodothyronine syndrome leads to a likely reduction in hospitalization. At the same time, the use of $\beta$-blockers in patients with low triiodothyronine syndrome results in an increased incidence of re-hospitalization. The re-hospitalization incidence in the group of patients with heart failure without low $\mathrm{T}_{3}$ syndrome is higher at a dose of $\leq$ $5.0 \mathrm{mg}$ (equivalent to bisoprolol), compared to a higher dose. The effect of $\beta$-blockers is reversed in low triiodothyronine syndrome: for this patients the risk of re-hospitalization for HF decompensation when the dose of $\beta$-blockers is over 5 $\mathrm{mg}$; a decrease in serum triiodothyronine level and in $\mathrm{T}_{3 \mathrm{f}} / \mathrm{T}_{4 \mathrm{f}}$ ratio, an increase in thyroxin; further enlargement of the heart cavities and reduction of the ejection fraction are observed.

\section{REFERENCES}

1. Jabbar A., Pingitore A., PearceS.H., Thyroid hormones and cardiovascular disease. Nat Rev Cardiol. 2017;14(1):39-55. doi: 10.1038/nrcardio.

2. Arcopinto M., Cittadini A. Hormonal alterations in heart failure: anabolic impairment in chronic heart failure - diagnostic, prognostic and therapeutic issues. Front Horm Res. 2014;43:57-69. doi: 10.1159/000360559

3. Fraczek M.M., Gackowski A., Przybylik-Mazurek E. et al. The relation between the low T3 syndrome in the clinical course of myocardial infarction and heart failure. Pol Merkur Lekarski. 2016;40(240):380-3.

4. Economidou F., Douka E., Tzanela M. et al. Thyroid function during critical illness. Hormones (Athens). 2011;10(2):117-24.

5. Wajner S.M., Maia A.L. New insights toward the acute non-thyroidal illness syndrome. Front Endocrinol (Lausanne). 2012;26:3-8.

6. Fraczek-Jucha M., Zbierska-Rubinkiewicz K., Kabat M., et al. Low triiodothyronine syndrome and selenium deficiency - undervalued players in advanced heart failure? A single center pilot study. BMC Cardiovascular Disorders. 2019;19:105. https://doi.org/10.1186/ s12872-019-1076-5.

7. Simonides W.S., Mulcahey M.A., Redout E.M. et al. Hypoxia-inducible factor induces local thyroid hormone inactivation during hypoxicischemic disease in rats. J Clin Invest. 2008; 118(3):975-83. doi: 10.1172/ JC132824.

8. Gereben B., Zavacki A.M., Ribich S. et al. Cellular and molecular basis of deiodinase-regulated thyroid hormone signaling. Endocr Rev. 2008 Dec;29(7):898-938. doi: 10.1210/er.2008-0019.

9. Arsanjani R., McCarren M., Bahl J.J. et al. Translational potential of thyroid hormone and its analogs. J Mol Cell Cardiol. 2011; 51 (4): 506-511. https://doi.org/10.1016/j. yjmcc.2010.12.012.

10. Fraczek M.M., Lacka K. Thyroid hormone and the cardiovascular system. Pol Merkur Lekarski. 2014;37(219):170-4.

11. Park K.W., Dai H.B., Ojamaa K. et al. The direct vasomotor effect of thyroid hormones on rat skeletal muscle resistance arteries. Anesth Analg. 1997;85(4): 734-11.14.

12. Hjalmarson A., Goldstein S., Fagerberg B. et al. MERIT-HF Study Group. Effects of controlled-release metoprolol on total mortality, hospitalizations, and wellbeing in patients with heart failure: the Metoprolol CR/XL Randomized Intervention Trial in congestive Heart Failure (MERIT-HF). JAMA 2000;283:1295-1302.

13. Tagami T., Yambe Y., Tanaka T. et al. Short-term effects of $\beta$-adrenergic antagonists and methimazole in new-onset thyrotoxicosis caused by Graves s disease (BBGD Study Group) Intern Med. 2012;51(17):2285-90. Epub 2012 Sep 1.

14. Ponikowski P., Voors A., Anker D. et al. ESC Guidelines for the diagnosis and treatment of acute and chronic heart failure 2016. The Task Force for the diagnosis and treatment of acute and chronic heart failure of the European Society of Cardiology (ESC) Developed with the special contribution of the Heart Failure Association (HFA) of the ESC. European Heart Journal. 2016;8: 123. doi:10. 1093/ eurheartj/ ehw128. 
15. Pyvovar S.M., Rudyk Yu.S., Lozyk T.V., Halchinska V.Yu. The features of "low T3" syndrome definition in a heart failure and its effect on a course of the disease. Zaporozhye medical journal. 2019; 4.21:437-443.

16. Voronkov L.G., Amosova K.M., Bagriy A.Ye. et al. Rekomendatsii Assotsiatsii kardiologov Ukrainy po diagnostike, lecheniyu i profilaktike khro-nochnoy serdechnoy nedostatochnosti u vzroslykh Kiyev. 2009;422. (In Ukrainian).

17. Larsen P.R., Zavacki A.M. Role of the lodothyronine Deiodinases in the Physiology and Pathophysiology of Thyroid Hormone Action. Eur Thyroid J. 2012;1;P. 232-242. doi: 10.1159/00034392212.

18. De Groot L.J. Non-thyroidal illness syndrome is a manifestation of hypothalamic-pituitary dysfunction, and in view of current evidence, should be treated with appropriate replacement therapies. Crit Care Clin. 2006:22(1);57-86. D0l: 10.1016/j.ccc.2005.10.001.

19. Hayashi T., Hasegawa T., Kanzaki H. et al. Subclinical hypothyroidism is an independent predictor of adverse cardiovascular outcomes in patients with acute decompensated heart failure. ESC Heart Fail. 2016; 3(3):168-176. D0l: 10.1002/ehf2.12084.

20. Gao R., Liang J.H., Wang L., et al. Low T3 syndrome is a strong prognostic predictor in diffuse large $B$ cell lymphoma British Journal of Haematology. 2017;177:95-105. doi: 10.1111/bjh.14528.

21. Iervasi G., Nicolini G. Thyroid hormone and cardiovascular system: from basic concepts to clinical application. Intern Emerg Med. 2013:8 (1):S7: 1-4. doi: 10.1007/s11739-013-0911-4.

22. Cantisani M.C., Parascandolo A., Perala M. et al. A loss of function genetic screening identifies novel mediators of thyroid cancer cell viability. Oncotarget. 2016; 7: 28510-28522. doi: 10.18632/oncotarget.8577.

23. Danzi S., Klein I. Thyroid disease and the cardiovascular system. Endocrinol Metab Clin North Am. 2014;43:517-528. doi: 10.1089/105072502760143836.

24. Dobre D., Veldhuisen D.J.van., Goulder M.A. et al. Clinical effects of initial 6 months monotherapy with bisoprolol versus enalapril in the treatment of patients with mild to moderate chronic heart failure. Data from the CIBIS III Trial. Cardiovasc. Drugs. Ther. 2008;22:399-405.

25. Torp-Pedersen C., Metra M., Charlesworth A. et al. COMET Investigators. Effects of metoprolol and carvedilol on pre-existing and new onset diabetes in patients with chronic heart failure: data from the Carvedilol Or Metoprolol European Trial (COMET). Heart. 2007;93(8):968-973.

26. Jessup M., Abraham W.T., Casey D.E. et al 2009 Focused Update: ACCF/ AHA Guidelines for the Diagnosis and Management of Heart Failure in Adults: A Report of the American College of Cardiology Foundation/ American Heart Association Task Force on Practice Guidelines Developed in Collaboration With the International Society for Heart and Lung Transplantation J. Am. Coll. Cardiol. 2009;53(15):1343 - 1382.

27. Wiersinga W.M., Touber J.L. The influence of beta-adrenoreceptor blocking agents on plasma thyroxine and triiodothyronine. J Clin Endocrinol Metab. 1977;45(2):293.

28. Perrild H., Hansen J.M., Skovsted L., Christensen L.K. Different effects of propranolol, alprenolol, sotalol, atenolol and metoprolol on serum T3 and serum rT3 in hyperthyroidism. // Clin Endocrinol (0xf). 1983;18(2):139.

29. JahagirdarV.R., Strouhal P., Holder G., Gama R., Singh B.M. Thyrotoxicosis factitia masquerading as recurrent Graves' disease: endogenous antibody immunoassay interference, a pitfall for the unwary. Ann Clin Biochem. 2008;45:325-327.
30. Fugazzola L., Persani L., Mannavola D. et al. Recombinant human TSH testing is a valuable tool for differential diagnosis of congenital hypothyroidism during L-thyroxine replacement. Clin Endocrinol (Oxford). 2003;59:230-236.

31. Rubio I.G., Silva M.N., Knobel M. et al. Peripheral blood levels of thyroglobulin Mrna and serum thyroglobulin concentrations after radioiodine ablation of multinodular goiter with or without pretreatment with recombinant human thyrotropin. J Endocrinol Invest. 2007;30:535-540.

32. Chopra I.J., Teco G.N., Nguyen A.H., Solomon D.H. In search of an inhibitor of thyroid hormone binding to serum proteins in nonthyroid illnesses. J Clin Endocrinol Metab. 1979;49:63-69.

33. Trummer C., Schwetz V., Aberer F., Pandis M., Lerchbaum E., PilzS. Rapid Changes of Thyroid Function in a Young Woman with Autoimmune Thyroid Disease. Med Princ Pract. 2019;28:397-400 https://doi. org/10.1159/000499754.

34. Natte I.S., Rangno R.E., van Loon G. Mechanism of propranolol withdrawal phenomena. Circulation. 1979;59:1158-64.

The article is a fragment of the scientific research work «To develop pharmacogenetic methods of prevention of decompensation of heart failure in patients with ischemic heart disease and thyroid dysfunction» (deadline - 2019-2021, state registration number 0119U001071).

\section{ORCID and contributionship:}

Sergiy M. Pyvovar: 0000-0002-9991-8027 ${ }^{A, B, C, D}$

Iurii S. Rudyk: 0000-0002-3363-868X ${ }^{E, F}$

Mykola P. Kopytsya: 0000-0003-4779-7347 ${ }^{E}$

Tetiana V. Lozyk: 0000-0001-8188-1898 ${ }^{\mathrm{E}}$

Valentina Ir. Galchinskaya: 0000-0002-0024-131X ${ }^{E}$

Tetiana O. Chenchik: 0000-0001-7170-5313 ${ }^{B}$

\section{Conflict of interest:}

The Authors declare no conflict of interest.

\section{CORRESPONDING AUTHOR Sergiy M. Pyvovar \\ Government Institution "L.T.Malaya Therapy National Institute of the National Academy of Medical Sciences of Ukraine" 2-a Lyubovi Maloy st., 61039 Kharkiv, Ukraine tel: +380677188896 \\ e-mail:sn_p@ukr.net}

Received: 10.10 .2019

Accepted: 15.04 .2020

A - Work concept and design, B - Data collection and analysis, C - Responsibility for statistical analysis, D -Writing the article, $\mathbf{E}$-Critical review, $\mathbf{F}$ - Final approval of the article 